\title{
Strategic Complementarities Between Innovation and Human Capital. The Neglected Role of Human Capital Demand*
}

\author{
Aurora Amélia Castro Teixeira \\ Assistant Professor, CEMPRE, ${ }^{* *}$ Faculty of Economics, University of Porto
}

Recebido em 10/11/2003 Aprovado em 22/3/2004

\section{ABSTRACT}

This study examines the conditions under which the demand for human capital is as (or more) important than the simple availability of educated or skilled human resources. The perspective taken is that it is the conscious and intentional attitude of firms, dependent, to a large extent, on respective strategies, that determines the demand for human capital, thereby conditioning the role of the latter in their performance. The automatic and linear character that many studies within the mainstream human capital theory assume is rejected here. Results, based on an in-depth study of fourteen Portuguese textile firms, reveal the "congruence" between firms behaviour towards human capital accumulation, characteristics of productive process and markets, and the omnipresent "fission" risk. New hirings of top skilled and educated individuals are seen as small contributors to firms (current) innovation capabilities. In contrast, existing top skilled and educated individuals are regarded as critical in this context.

I would like to acknowledge three anonymous referees for their detailed and useful comments and suggestions. Any errors are my own.

** CEMPRE - Centro de Estudos Macroeconómicos e Previsão - is supported by the Fundação para a Ciência e a Tecnologia, Portugal, through the Programa Operacional Ciência, Tecnologia e Inovação (POCTI) of the Quadro Comunitário de Apoio III, which is financed by FEDER and Portuguese funds. 
Aurora Amélia Castro Teixeira

\author{
KEYWORDS $\quad$ Human Capital; Innovation; Inertia \\ JEL CODES I J24; O32; Z00
}

\title{
RESUMO
}

Este estudo analisa as condições em que a procura por capital humano é tão (ou mais) importante do que a simples disponibilidade de recursos humanos qualificados. É tomada a perspectiva de que é a atitude consciente e intencional das empresas, a qual depende em grande medida das suas estratégias, que determina a procura por capital humano, condicionando o seu desempenho econômico. Rejeita-se aqui o caráter automático e linear presente na maioria dos estudos associados à teoria do capital humano. Os resultados, baseados num estudo detalhado de 14 empresas têxteis portuguesas, revelam a "congruência" entre o comportamento destas relativamente à acumulação de capital humano, as características dos seus processos produtivos e mercados e a onipresença do risco de "cisão". As novas contratações de indivíduos altamente qualificados são vistas como contribuindo pouco para as competências de inovação correntes das empresas. Em contraste, os atuais trabalhadores de altas qualificações são considerados essenciais nestes domínios.

PalaVRas-Chave $\mid$ Capital Humano; Inovação; Inércia

Códigos JEL | J24; O32; Z00

\section{Introduction}

The present paper attributes particular emphasis to the role of human capital demand in firm strategies and policies. The perspective taken is that it is the conscious and intentional attitude of firms, dependent, to a large extent, on the respective strategies (of market, product and process), that determines the demand for human capital, thereby conditioning the role of the latter in their performance. Therefore, the automatic and linear character that many studies assume is rejected here. 
In particular, this study examines the conditions under which the demand for human capital is as (or more) important than the simple availability of educated or skilled human resources. To the extent that these conditions are reproduced elsewhere, problems in generating effective demand explain the persistence of significant regional disparities and the existence, particularly in certain areas, of a "vicious cycle" characterized by low education — low skills - and weak income levels. In this cycle, a self-reinforcing group of public institutions (namely, the education and training system) and private (firms and families) seem to interact in restricting the demand for high levels of education and skills. The research analyses the specific demand conditions that give rise to this "low level" equilibrium trap, provides further confirmatory evidence for the "fission" model introduced in Teixeira (2003), and considers qualitative evidence about the behaviour of Portuguese textile firms in the accumulation and deployment of skilled labour.

The paper is structured as follows. Section 2 briefly accounts the relationship between human capital and innovation capabilities at firm level. Then, in the following section, a glance on the recent evolution of the Portuguese textile industry concerning human capital accumulation is provided, which simultaneously helps to rationalise the methodological framework pursued in the research. In Section 4 the methodology used in the elaboration of the study is outlined (namely, the process of gathering and treating information provided by the firms) and the selected firms briefly characterized. Section 5 presents the empirical analysis where the fourteen firms are aggregated into "clusters" of performance. This aggregation serves as the basis for the analysis of the process of building firm technological competences (Section 6). In the following section (Section 7) the issue of fission is highlighted and the relation between technological competences and human capital analysed. Finally, Section 8 concludes the paper summarising the main results of the research.

\section{Human capital and innovation. Theoretical underpins}

The works of Theodore Schultz and Gary Becker, which constitute the foundations of human capital theory, provided for the first time a comparative 
insight into the incentives for the accumulation of capabilities (Schultz, 1961a, b; Becker, 1962). Other (previous) authors have written about capital, and some of these did recognize that the productive powers of individuals could be augmented by the accumulation of skills or capabilities (much like improving a physical capital good), however, these latter do not offer the richness of analytical capabilities of the modern definition of "human capital". Adopting the human capital framework regarding the measurement of the human capital concept, the present study considered a somewhat broad notion of it, which included (formal) education, on-the-job learning and skills.

The work pursued in the present paper highlights and tries to overcome several pitfalls of the mainstream economics regarding human capital issues. Firstly, education and training are seen by orthodox human capital theory to improve performance in an unproblematic manner by making people more productive workers (Ashton \& Green, 1996). It remained to be clarified, however, how some forms of skill formation have much more impact on performance for some groups of workers rather than others. Factors of production, in particular different types of workers, may not be so easily substituted for each other as human capital theory assumes. Lock-in effects on the production side, as well as the institutional context, may severely diminish the scope for substitution possibilities. Secondly, the existing theoretical and empirical literature relating to the human capital theory approach, as already noted, involves resorting to the belief that employers must be ill-informed or irrational to explain why there remain distinctly low limits on the demands they place on the education and training system (Teixeira, 2002a). None of the authors following this theoretical approach have focused attention upon the determinants of demands for human skills and how those demands change. As the "demand" side in rate of return studies is already incorporated recurrently in the formulation of the incentives for accumulation given the existence of labour market equilibrium, in studying supply one is studying demand as well. If there were an insufficiency of demand for higher levels of human capital, the incentives for its accumulation would be lower and the supply would automatically adjust to the demand.

The present study attributes particular emphasis to the role of human capital demand in firm strategies and policies. In the line of Senker and Brady (1989), it is assumed that it is the conscious and intentional attitude of firms, 
dependent, to a large extent, on the respective strategies (of market, product and process), that determines the demand for human capital, thereby conditioning the role of the latter in their performance.

\section{The neglected role of human capital demand. The case of the Portuguese textile industry}

Despite the manifest educational backwardness of Portugal relative to its main European counterparts, it is undeniable that, after the 1974 Revolution, and more particularly in the last twenty years, human capital (more precisely, its educational and training components) has been elevated to the status of a political and social priority (Teixeira, 1999). In the same period, human capital demand growth, as reflected in the evolution of the education levels of people employed in establishments, was positive, with a more pronounced increase at higher schooling levels. However, in the manufacturing sector, and in particular in "low skill" industries, " the capacity to absorb the increasing availability of better-educated human resources in the period in question has been limited. Between 1984 and 1992, the weight of top skilled professionals (including medium level) in low skill (and low capital intensity) industries did not change, remaining at a very low share compared to the manufacturing average. In addition, the importance of top educated individuals barely changed, contrasting again with manufacturing industry as a whole (Teixeira, 2002b). In general, the evolution of human capital demand in "low skill industries" seems to have put pressure on the availability of low or non-skilled and poorly educated human resources. As studies by Batista $(1994,1996)$ elucidate, the highest percentage of job vacancies in the textiles and clothing industries ${ }^{2}$ (which constitute the bulk of low skill, low capital intensity industries) are in the lowest education levels (second and first cycles of basic education). The highest

\footnotetext{
1 "Low skills" industries encompass two types of industry, those with "low skills and low capital-labour ratio" — textiles, clothing, leather, footwear, wood, furniture, metals and other manufacturing, and those with "low skills and high capitallabour ratio" - food, beverages, ceramics, glass, cement, and ornamental rocks. Between 1984 and 1993 low skill industries increased their relative importance in Portuguese manufacturing industry. In 1993, low skills activities represented almost two-thirds of manufacturing value-added as against $45 \%$ in 1984. In terms of employment, $68 \%$ of the total manufacturing workforce was employed in low skilled activities in 1984, increasing to three quarters in 1993 (GEPIE, 1995).

2 Despite being related, textiles and clothing constitute two very distinct segments. Clothing encompasses operations such as design, development, cutting and assembling of woven under- and outer-wear garments. The textile industry covers all the remaining segments of the textile complex (e.g., spinning, weaving, finishing, dyeing, printing).
} 
percentage of entries and exits also occurred in these education groups, which seems to indicate that in these industries firms continue to replace poorly educated labour by labour with identical education levels, despite the increasing availability in the labour market of better educated individuals. Moreover, recruitment difficulties concerning human resources with tertiary education ${ }^{3}$ (polytechnic and university) are, in these industries, almost non-existent.

Textile and clothing industries constitute one of the largest industrial sectors in the European Union but in Portugal its importance is far more critical, representing in $1997,17 \%$ of manufacturing value added and almost thirty per cent of manufacturing total employment. ${ }^{4}$ Moreover, $22 \%$ of Portugal's total exports originated in the textiles complex, it being the major exchange earner. In terms of human capital traits, the Portuguese textile (and clothing) industry in the last three decades has been characterized essentially by a low or non-skilled labour force, poor quality and low productivity (Godinho, 1993; Lopes, 1996; Lourenço \& Mendes, 1996). It is interesting that a substantial number of studies focusing on the textile industry seem unanimous in attributing the main structural deficiencies of textiles to this industry's human capital endowments.

Whereas throughout the world, and particularly in the more advanced economies, there has generally been an unequivocal trend toward increasing diversification and technological sophistication in the textile industry (Singleton, 1997), the relative labour intensity of the Portuguese textile industry has proven to be both sustained and persistent.

The Portuguese textile industry suggests thus that the increasing availability of better educated and higher skilled individuals in the labour market is not a sufficient condition for improvement in employment distribution. The demand side of human capital presents, in fact, a high degree of inertia relative to the supply side in this industry. It seems necessary therefore to bring to the forefront the neglected human capital demand side and examine the factors that may be inhibiting diversity, in terms of product outputs and the associated employment practices.

Although in part the relative inertia in human capital demand observed

\footnotetext{
3 The first cycle of education corresponds to four years of schooling while the second cycle to six years.

4 The European Union corresponding figures were, in that same period, respectively $4.2 \%$ and $7.6 \%$ [figures taken from APIM (1998)].
} 
at macro economy level in Portugal might be explained by this country's industrial specialization pattern, namely the relative concentration of the Portuguese industrial sector in the textile filière, this does not explain why, within the same industry, there are so many distinct patterns. A more microeconomic analysis, focusing on firm product and market strategies, might help to unravel this issue. Thus, conditioned by the aim of the research, the choice of in-depth and comparative case study methodology was particularly straightforward.

In fact, according to the methodology employed, combining qualitative and quantitative elements, it is considered to be more appropriate when "how" and "why" questions are being asked about a past or current phenomenon drawing on multiple sources of evidence (Yin, 1994). This is the case with the present research. Although results obtained through this methodology cannot be generalized to populations (statistical generalizations) they can be, nevertheless, generalized to theoretical propositions — analytical generalizations (Yin, 1994).

\section{Some considerations on the methodology}

\subsection{Sampling criterion and description of the fieldwork}

The empirical work presented in this paper is based on a detailed study of fourteen textile firms over the period 1988-1997. Firms that collaborated in this research were drawn from a random sample of 50 firms which answered to Quadros de Pessoal in 1996, an annually compulsory survey, conducted by the Portuguese Employment Ministry alongside every firm with one or more paid employee. Of these fifty firms, 17 accepted collaborate in the research. The first set of visits was made in the period from December 1997 up to the end of January 1998. Each visit lasted, on average, three hours and involved an interview with the owner or firm's manager and a guided "tour" of the firm's shopfloor. The second round of visits occurred between November 1998 and January 1999 and, on average, each visit (now restricted to 14 firms which permitted accessing further detailed information) lasted one and a half days (for smaller firms generally one day, whereas larger ones lasted two to three days). The information gathered was structured into five different but interrelated questionnaires covering the period 1988-1997. The five questionnaires were 
completed with the cooperation of the owner/executive manager, in the case of small and medium firms, and the cooperation of the owner (in some cases) and top professional staff in the case of large firms. ${ }^{5}$ These last, in the majority of cases, were individuals connected to several departments within the firm, namely, human resources, production and financial managers. The combined information from these five questionnaires enabled the analysis that is presented in the following sections.

\subsection{Brief characterization of the firms ${ }^{6}$}

Similarly to the whole textile industry, where almost $80 \%$ of firms are located in the North Region, a significant number (12 out of 14) of the firms selected are also located in this region. The sample in the study, however, has a clear bias towards larger units. In fact, the majority of firms selected (11 out of 14) is relatively large compared with the industry's population, employing more than 100 workers. This contrasts with the situation at the level of the industry where relatively small plants constitute the bulk of the firms - units employing less than 50 workers represent more than three-quarters of total textile firms. $^{7}$

On the whole, these fourteen firms represented 6,3\% and $8 \%$ of Portuguese textile industry total employment and sales, respectively. ${ }^{8}$ Considering the 1997 ranking of the 100 largest Portuguese textile and clothing firms, eleven out of the fourteen firms studied were in that list, being four of them in the top ten. ${ }^{9}$

5 The first questionnaire, relative to firm technological competences, includes the innovation efforts of the firm at the level of markets, products and processes, as well as the respective external linkage efforts. The process of human capital accumulation is investigated through the second questionnaire. This questionnaire focuses on two aspects: the human capital trajectory of human resources chief executive, and the process of organization and provision of vocational training activities. The third questionnaire, is essentially quantitative, detailing the structure and evolution of the corresponding employment. Technical performance is the subject of the fourth questionnaire. Here the state of existing equipment (age, type, rate of utilization); modernization process (acquisition and improvement of equipment), and eventual associated changes at the level of human capital endowments are analysed. Finally, economic and financial performance is analysed through the fifth questionnaire, which essentially involves information gathered from the firm's financial reports. These questionnaires are included in Teixeira (2002b, Appendix 13).

6 The data gathered refer to 1997.

7 Data from INE respecting 1993.

8 Portuguese textile industry total employment and sales data from Anuário Estatístico do INE, 1999.

9 Jornal de Notícias, 1997, 1000 maiores empresas portuguesas. 
Although the smaller firms in the analysis present a lower capital-labour ratio (less than 40.000 Euros per worker/year), there does not appear to be evidence of a strong association between firm size (in terms of the number of workers) and respective capital intensity. It is interesting to note that the vast majority of the firms had had long experience in their respective business; 12 firms have been in existence for more than 25 years, four of them established for over half a century. In terms of industry composition, four firms belong

TABLE 1

Human capital intensity (top educated and top skilled workers as percentage of firm total employment) of the firms in study, by district, industry and size

\begin{tabular}{|c|c|c|c|c|c|c|c|c|c|c|c|}
\hline \multirow[t]{2}{*}{ District } & \multirow[t]{2}{*}{ Industry } & \multicolumn{5}{|c|}{ Top Educated (\%) } & \multicolumn{5}{|c|}{ Top Skilled (\%) } \\
\hline & & $50-99$ & $100-199$ & $200-499$ & $500+$ & Average & $50-99$ & $100-199$ & $200-499$ & $500+$ & Average \\
\hline \multirow[t]{3}{*}{ Braga } & Spinning of cotton & & & 2.4 & & 2.4 & & & 3.3 & & 3.3 \\
\hline & Weaving of cotton & & & 1.9 & 2.9 & 2.6 & & & 14.8 & 5.0 & 9.9 \\
\hline & Knit & & & 4.2 & & 4.2 & & & 3.5 & & 3.5 \\
\hline $\begin{array}{l}\text { Castelo } \\
\text { Branco }\end{array}$ & Weaving of wool & & & & 3.5 & 3.5 & & & & 3.0 & 3.0 \\
\hline \multirow[t]{3}{*}{ Porto } & Finishing & & 2.8 & 5.1 & & 3.9 & & 6.1 & 8.1 & & 7.1 \\
\hline & Other textiles & 1.7 & & & & 1.7 & 3.4 & & & & 3.4 \\
\hline & Ropes and cables & & & 4.1 & 1.8 & 3.0 & & & 4.8 & 2.8 & 3.8 \\
\hline Leiria & Other textiles & & & 0.5 & & 0.5 & & & 2.4 & & 2.4 \\
\hline Average & $(\%)$ & 1.7 & 2.8 & 3.0 & 2.8 & 2.8 & 3.4 & 6.1 & 6.2 & 4.1 & 4.7 \\
\hline Number of & firms & 2 & 1 & 6 & 5 & 14 & 2 & 1 & 6 & 5 & 14 \\
\hline
\end{tabular}

Note: Top educated' — individuals with tertiary education; "Top skilled" — individuals classified as top and medium boards. Source: Author's calculations based on data gathered from direct interviews and questionnaires to fourteen Portuguese textiles firms between November 1998 and January 1999.

to "Weaving of cotton". "Finishing" and "Ropes and Cables" present two firms each whereas "Spinning of cotton", "Knit" and "Weaving of wool" present one firm each. The remaining three firms belong to "Other textiles". Regarding the human capital intensity, the data reveal a picture analogous with that of the textile industry as a whole. 
Indeed, although the group of selected firms presents a slightly higher than average proportion of individuals with high levels of human capital than that of the whole industry $(2.8 \%$ against $1.5 \%$, for top educated, and $4.7 \%$ against $4.6 \%$ for top skilled, respectively), the configuration of their employment structure in terms of human capital is very similar — "limited core of top educated and skilled workers and a large 'reserve army' ${ }^{10}$ of low educated and skilled workers". ${ }^{11}$ As is detailed later in this study, in this group of firms, similar to the industry as a whole, inertia in human capital demand seems to be a pervasive phenomenon.

\section{Estimating the clusters of performance}

\subsection{The operationalization of the performance concept}

Two performance dimensions are considered: the economic and the technological. The latter is unfolded into three components: technical competence, innovation capability and external linkage capability (firm's capacity to relate to external entities, such as clients, suppliers, consultants, employers and industrial associations, technological centres, and universities or higher and professional education institutes). ${ }^{12}$

Economic, technical, innovation and linkage performance concepts are operationalized using the following indicators:

\footnotetext{
10 Although the expression "reserve army" is due to Marx (1887) for referring those workers who were excluded from the capitalist production process, the meaning of this expression in this paper is different, aiming to encompass those individuals that participate in the productive process but that are relatively marginal to that same process because of their low education and skills levels. The author acknowledges one of the referees for calling attention to such important detail.

11 Low educated workers (individuals with 6 or less years of education) correspond in the selected firms to an average of $81 \%$, whereas the industry average is $86 \%$. The proportion of low or non-skilled workers in the sample is $44 \%$ and in the industry as a whole is $43 \%$ (industry averages respect are forthe year of 1995 and were computed from unpublished data supplied by DE_MQE). The fact that the group of selected firms is biased towards large units justifies, in to a large extent, the differences obtained in top educated and skilled categories relative toly the industry as a whole. Recall that in textiles over three-quarters of the firms have less than 50 workers. In the (non-representative) sample analysed here, all firms have more than 50 workers (and 11 out 14 have more than 200 workers).

12 A dynamic approach to performance was taken, i.e., in terms of growth rates. Since the information gathered spans, in the large majority of the cases, the period 1988-1997, the performance indicators were calculated in relation to more recent periods, namely, 1992-1997 and 1994-1997. The reason for such a limitation in terms of the reduced time period covered, derives from the significance of temporary lags (a certain time is required for the influence of firm strategic decisions to show up in terms of performance), and the possibility that this alternative gives to analyse the relative importance of stocks (past or initial levels) and flows/investments (growth rates) of human capital for firm performance dynamics.
} 
- LPROD9297 - "economic performance" — annual average growth rate as a percentage of labour productivity (gross value added/ employees), at current prices, 1992-1997;

- EQPROD9297 - "technical performance" — annual average growth rate as a percentage of the physical capital productivity (gross value added/ gross fixed assets), between 1992 and 1997;

- INNOV9497 — "innovation performance" — innovation actions (market, product and process) as a percentage of the total number of innovation actions performed internally by the firm in the last three years of the period under study (1994-1997);

- LINK9497 — "linkage performance" — weighted average of routine (weight=1) and innovation (weight=3) actions (market, product and process) jointly performed by the company with external entities in the last three years (1994-1997). ${ }^{13}$

On average, firms with high economic performance also achieve good technical performance. ${ }^{14}$ Thus, due to the almost perfect correlation between the economic and technical indicators, these can be used, almost without distinction, as a way of classifying firms into groups according to productivity growth. Relating to the remaining performance indicators (innovation and linkage), estimates of the correlation coefficients between them and indicators of economic and technical performance are positive but not (statistically) significant. ${ }^{15}$ There is, therefore, not enough statistical evidence to state that

13 In questionnaire one concerning "Firm technological competences" the respondent (in the majority of the cases, the owner) was asked to indicate, from a list of 17 innovation actions (four market, four product, and nine process) and 20 routine actions (10 market, six product and four process), those that in the last three years (1994-1997) were performed by the firm and, of these, which ones had been performed with the collaboration of external entities (clients, suppliers, consultants, technological centres, industrial and employer associations, universities and other). In the computation of INOV9497 for each firm account was taken of the total number of innovation actions indicated by the firm divided by the total number of innovation actions listed (cf. table above). In the case of LINK9497, for each firm both routine and innovation actions were considered, which were performed with the collaboration of external entities, and their numberis was then divided by the number of actions listed. Note, however, that here was used not a simple average but a weighted average was used, a higher coefficient being attributed to innovation actions (3) than to routine actions (1). It is assumed thus that, in general, innovation actions are more complex than routine actions, requiring higher linkage competences.

${ }^{14}$ Computing the Pearson linear correlation coefficient, a strong positive association $(\rho=0.91)$ was observed, between labour and capital productivity growth rates (annual average), that is, between firms' economic and technical performances, in the period 1992-1997. Note, however, that if instead of labour productivity another economic indicator is used, for instance, sales, economic and technical, the statistical correlation would not be as significant. In fact, the estimate of the correlation coefficient in this case would be 0.60 and its statistical significance level would be $10 \%$.

15 The Pearson correlation between economic [technical] and innovation and linkage performance are, respectively, 0.28 [0.21] and 0.33 [0.26], failing to be statistically significant. 
firms with excellent performance at the economic and technical levels also present high innovation and linkage performances. However, the statistical analysis does verify that a reasonable statistical association exists between innovation and linkage measures of performance. ${ }^{16}$

Although, individually considered, the innovation and linkage indicators do not show strong correlations with the indicator of economic performance this latter reflects, in a quite satisfactory way, "aggregated performance". ${ }^{17}$ Therefore, the choice was made to use the (labour) productivity (annual average) growth rate as the major indicator of performance. ${ }^{18}$

\subsection{Building performance clusters}

In the attempt to classify the firms in the study according to the degree of "proximity" of their productivity growth in the period 1992-1997, it was decided to resort to the statistical procedure of "cluster analysis". ${ }^{19}$

Here the interest is to assess the degree of similarity/distance amongst the fourteen Portuguese textile firms in the study in terms of their performance (i.e., productivity change, proxied by the annual average growth rate of value added per worker between 1992 and 1997). In this vein, firms are grouped on

\footnotetext{
16 The Pearson correlation coefficient is 0.49 , being statistically significant at $10 \%$.

17 The "aggregated performance" indicator was computed having as a base the four performance measures referred to. For each of these measures the ranking of firms was obtained by increasing the order of the corresponding variable (in such a way that higher rank correspond to higher performance values), and then computing the simple average of those rankings. The correlation of "aggregated" performance is highest with the economic performance indicator (0.80). The remaining estimates for correlation coefficients are $0.70,0.68$, and 0.66, for INOV9497, EQPROD9297 and LINK9297, respectively.

${ }^{18}$ Note that the measure of productivity has a problematic relationship with profitability because it has no control for changes in the capital labour ratio. Any firm that increases this ratio is likely to experience higher levels of output per worker (i.e., increased productivity) since such increases are required to pay the costs of the additional capital. If opportunities for labour-saving or revenue-increasing capital investment do not exist, the capital labour ratio is less likely to change and the association of value added per worker with productivity is entirely justified. It is still possible that work re-organization may lead to labour being released, which is a kind of productivity improvement. Notwithstanding, "high productivity" in the way that it is measured throughout this study (as value added per employee) already takes into account revenue productivity and, in this sense, there should be few problems in associating high "measured productivity" with high relative profitability. Nevertheless there still are some discrepancies between these two indicators which are important to highlight and that justify the choice for the "productivity" measure, namely those deriving from the possibility of high capital costs, the possibility that the wage structure of the firm is somehow out of line or, some accounting problem in measured profits. The first two results in costs absorbing the margin that otherwise would be available from high value added per employee.

19 The statistical software used here was the SPSS $10.0{ }^{\circledR}$. Norusis (1994) provides more details about the technique in question.
} 
the basis of their "nearness" concerning productivity dynamics. ${ }^{20}$ The results of the cluster analysis are summarized in the agglomeration schedule, which identifies the firms or clusters being combined at each stage. Following a heuristic-based method, agglomeration stopped at stage 9 involving thus 5 clusters: 1) "very strong growth"; 2) "strong growth"; 3) "moderate growth"; 4) "weak growth" and 5) "decline".

As can be seen in Table 2, five of the fourteen firms in the study experienced a strong or very strong growth in productivity, with average (current) growth rates around $9 \%$ and $20 \%$, respectively. ${ }^{21}$ Six firms displayed moderate growth (around 5\% per year), the performance of the remaining three being well below the overall average (7.3\% per year). Considering the average annual inflation rate in the period under analysis was $4.6 \%$, it can be concluded that the real performance of the last three clusters (3, 4 and 5), comprising nine of the fourteen firms, was clearly weak: stagnating in the case of cluster 3 , with a real average growth rate of $0.5 \%$ per year, or declining $-2.5 \%$ and $-5.6 \%$ per year, respectively, for clusters 4 and $5 .{ }^{22}$ In contrast, the first two clusters, which comprise five firms, showed strong growth, with real growth rates reaching $15.8 \%$ and $4.7 \%$, respectively, compared to both the remaining firms in the sample and the Portuguese economy's managerial sector. In the managerial sector in Portugal, the real rate of growth reached $2 \%$ per year, in the period under study. ${ }^{23}$

The change in productivity (value added/employment) in the sampled firms derives, essentially, from "cluster" specific trends in gross value added. Indeed, in the case of the first three clusters the employment level, between 1992 and 1997 either remains constant or decreases slightly (cluster 2). More

\footnotetext{
20 Despite the existence of many different ways of measuring distances between cases (firms, in this instance), here one of the most common, the squared Euclidean distance, is used. This is the sum of the squared differences over the variable in question (productivity change). In addition, for combining the 14 textile firms into clusters, the agglomerative hierarchical clustering method is used. According to this method, clusters are formed by grouping firms into bigger and bigger clusters until all of them are members of a single cluster. At the outset, each firm is considered as a separate cluster (there are as many clusters as there are firms, i.e., 14). At every subsequent step, either individual firms are added to existing clusters, or two existing clusters are combined. Once a cluster is formed, it cannot be split; it can only be combined with other clusters - the criterion chosen for deciding which firms or clusters should be combined at each step is the between-groups linkage, the default method in the SPSS $10.0 \AA$ package.

${ }^{21}$ Note that productivity, as well as other economic indicators, is given at current prices, i.e., it includes price effects. In interfirm comparisons it is not relevant whether monetary aggregates are deflated or not, but this is not the case when one wants to perform a time comparison.

22 Mean value of annual inflation rates (based on the Consumer Price Index, excluding housing rents) between 1992 and 1997 (source: INE).

${ }^{23}$ Value from 1997 Bank of Portugal's Annual Report (Banco de Portugal, Relatório Anual 1997, p. 62).
} 
TABLE 2

Clusters of performance in terms of productivity growth, 1992-1997

\begin{tabular}{l|l|ccccc}
\hline Clusters & Designation & $\begin{array}{c}\text { Number } \\
\text { of firms }\end{array}$ & \multicolumn{4}{c}{ Average values of annual average rates (\%), } \\
$1992-1997$
\end{tabular}

Note: PROD — productivity (GVA/EMP); GVA — gross value added; EMP — Employees; TURN — firm total sales and services.

Source: Author's calculations based on data gathered from direct interviews and questionnaires to fourteen Portuguese textiles firms between November 1998 and January 1999.

symptomatic is the case of the firm belonging to the cluster "decline", where the significant fall in employment (-2.6\% per year) was not sufficient to compensate for the larger drop in value-added, resulting thus in decline in (nominal and real) productivity.

\section{Technologic competences by performance clusters}

\subsection{Commercial competences}

Of the total number of answers (22) to the question "In your opinion, given the characteristics (price, quality, design) of your nearest competitors' products, in which market segment do you position your company's products?", the most quoted market segment is the medium-high, with $50 \%$, followed by the medium-low market segment with $23 \%$ of total answers. Although this allocation procedure of products in the different segments being based on interviewees' opinions is subjective, it reflects, nevertheless, the importance attributed by the lowest (low and medium-low) market segments, which include approximately $32 \%$ of total answers. The relevance of this percentage appears more significant if one takes into account that similar studies performed in Italy 
and Germany at the beginning of the 1990s, produce corresponding figures well below those found in the present study (10\% in Italy and 2.5\% in Germany). ${ }^{24}$

The data reveal a direct relationship between size and the number of market segments targeted — firms that target more than one market segment have more than 500 employees. Some of these large firms did however, indicate that it was the lower range markets (produced in large quantities) that allowed them to obtain reasonable profits and, simultaneously, to maintain their size. Notwithstanding this, they recognized that, in recent years, the corresponding margins have decreased considerably due to the competition from countries with wages and other costs (much) lower than those in Portugal. Moreover, and in financial terms, these standard products have been serving as a support base for a strategy targeting the upper market segments. The reduced percentage of answers in the high segment of the market $(9.1 \%$, which is tiny compared with the $22 \%$ found in the Italian study), however, highlights the still very incipient character of those strategies. Note that in the highest segments of the market the competition is fiercer than in the lowest segments; what changes are the actors, with the developed European countries (namely Italy, Switzerland and Germany) in the leadership. The capacity for design in Italy, the high quality of Swiss products or the technical supremacy of the Germans constitute almost unbeatable competitive barriers (at least currently) for most Portuguese textile firms, where the shortage of human resources in these areas is usually pointed to as being the greatest hindering factor. The evidence presented in Teixeira (2002b, 2003), however, does not support the "human capital shortage" argument. Instead, Portuguese textile firms (of which the group under study in this research can be taken as a reliable example) seem to present a quite conscious and intentional behaviour, opting (rationally) for technologically stable, less demanding, but still profitable, markets. In a context pervaded by the fission risk, such behaviour magnifies even further the inertia observed on the human capital side.

Questioned about the main comparative advantages of their products (price, quality, design, period of delivery or other), the majority (57\%) of chief executives considered quality to be the most important comparative advantage of their firms. Design was considered to be a critical comparative advantage for just

\footnotetext{
24 The Italian study (in Navaretti and Perosino, 1995) is based on an inquiry covering 11 textile firms and 13 clothing firms, whereas the German study (in Piatti and Spinanger, 1995) is based on a study covering nine textile firms.
} 
two firms in the sample, and these were the firms with the best performance in the five most recent years of the study (1992-1997). Price continues to be an important competitive variable for four of the fourteen studied firms. The "quality-delivery time" is particularly important for firms in the ropes and cables sector. Here, product performance (resistance, durability, satisfaction of specific technical requirements), allied to a capacity for rapid answers, constitute the key to the success and the survival of the business.

The majority of firms use commercial agents (at the level of the external market) or their own salespersons (in the domestic market) as the most important channels of product distribution. ${ }^{25}$ There seems to be a serious deficiency in the control of distribution channels, at least at the external level, the most important market for the majority of selected firms. Apparently, the data do not enable any forecast of a relationship between productivity growth and the form and degree of dominance of the distribution channels. However, interviews provided valuable information in this respect. The most dynamic firms already show some level of concern about how their products are distributed. Three of the five firms that constitute the first two clusters already implement several points of direct sale, at both the domestic and external levels (in the latter case, essentially, through joint-ventures or cooperation with firms/agents from product destination countries). One of the two firms in the "weak growth" cluster presents a good commercialization basis, having already performed two joint ventures at the external level, and possessing several sale points internally. The relatively weak performance of this company is not at all conditioned by its commercial strategy; instead it derives from deficiencies at production level, namely, outdated layout in face of a new product mix, and need for modernization in production equipment and computing systems. The strong commercial basis and the (high) know-how in terms of external linkages that this company possesses must constitute two important factors favouring its promising recovery.

From the above it might be concluded that, to a certain extent, firm performance seems to be associated with more active commercial strategies translated into increasing domination of the distribution channels. These strategies, however, are essentially entrepreneurially driven and do not require

${ }^{25}$ Firms with better performances are essentially exporters. Thus, in this sample, and similarly to the whole Portuguese economy, there is a high dependence on the external market as an engine of growth (Afonso \& Aguiar, 1997). 
substantial additions of human capital. In fact, in the case of three firms from the two highest performance clusters and one from the "weak" cluster, the dynamics concerning marketing distribution arrangements have relied, essentially, on the efforts and capabilities of the entrepreneur and the existing top skilled workers. According to information based on direct interviews, there are no plans to hire (or need to hire) additional (top skilled or educated) individuals to deal with issues relating to commercial strategies.

\subsection{Market, product and process competences}

As one could expect, all firms reveal some competence to accomplish routine actions internally at the level of the processes, that is, related to the organization and planning of the productive process. At product level and, more especially, at market level, competences are higher in larger firms, namely those that constitute the "strong growth" cluster. Despite the divergences in levels of these firm competences, this does not seem to explain the different productivity dynamics (performances) of the firms under study.

At the level of innovation capacity, only in the case of market innovation is there evidence of higher capacity on the part of the most dynamic firms. At the level of products and processes, excluding the "moderate growth" cluster, which includes smaller firms, the propensity to innovate does not seem very different among groups with distinctive performances.

TABLE 3

Competences at market, product and process levels - innovation actions

\begin{tabular}{lccc}
\hline & \multicolumn{2}{c}{ Percentage of total innovation actions } & performed internally by the firm \\
\hline & Market & Product & Process \\
Very strong & 63 & 25 & 72 \\
Strong & 50 & 33 & 89 \\
Moderate & 38 & 5 & 52 \\
Weak & 0 & 25 & 83 \\
Decline & 25 & 25 & 78 \\
Overall Average & 40 & 18 & 69
\end{tabular}

Source: Author's calculations based on data gathered from direct interviews and questionnaires to fourteen Portuguese textiles firms between November 1998 and January 1999. 
Once again, a clear pattern of technological stability in the firms analysed is uncovered, which is likely to strengthen the impact of fission on the (inertia of) human capital side.

\subsection{Organizational competences}

Concerning organizational competences, chief executives were asked to characterise their firms by choosing one of several statements describing the degree of integration and hierarchical structure of their firms. The majority (almost 80\%) of chief executives responded that their respective companies are integrated [at all the levels (3), just at level of the administration (2) or at administration, marketing and design level (6)].

Despite the opinion of the majority of chief executives about the relatively integrated character of their respective firms, additional information gathered (in interviews) concerning the nature and structure of tasks performed within those firms questions, in part, these chief executives' claims. In fact, this information reveals, for all firms in the study, an organizational process, essentially at production or shop-floor level, with remarkably Taylorist characteristics. The simple and repetitive tasks prevail; work variety and workers' self-control in the execution of the tasks is almost non-existent; there is a separation between production execution, conception and control functions. This Tayloristic-based organisation method has, nevertheless, as Kovács et al. (1993) demonstrate, been the method that allows production processes based on a low skilled labour force to be explored more effectively and, thus, is adequate to the relatively labour intensive character of textile firms, in general and the Portuguese in particular.

In this vein, it can be argued that labour organization features, similar to other specificities of the selected firms (e.g., target markets and distribution arrangements), constitute powerful contributors alongside (and reinforcing) the fission mechanism for the pervasiveness of "inertia" at the level of human capital demand in the Portuguese textile industry.

The detailed features of "inertia" in the firm are also particularly evident in the behaviour of firms regarding the deployment of new technology. Indeed, according to the chief executives, the introduction of new technologies has not 
TABLE 4

Organisational competences - description of the productive process

\begin{tabular}{|c|c|c|c|c|c|c|}
\hline & \multicolumn{5}{|c|}{$\begin{array}{c}\text { Frequency of situation (Average) } \\
{[1-\text { never; } 2 \text { - seldom; } 3 \text { - often; } 4 \text { - always] }}\end{array}$} & \multirow[t]{2}{*}{$\begin{array}{l}\text { Global } \\
\text { average }\end{array}$} \\
\hline & Very strong & Strong & Moderate & Weak & Decline & \\
\hline $\begin{array}{l}\text { Workers perform simple easily } \\
\text { executable tasks }\end{array}$ & 3.0 & 3.3 & 3.0 & 2.5 & 3.0 & 3.0 \\
\hline $\begin{array}{l}\text { There is a repetition of the same } \\
\text { task by the same worker }\end{array}$ & 3.0 & 3.3 & 2.7 & 2.5 & 3.0 & 2.9 \\
\hline $\begin{array}{l}\text { There is only one job post for } \\
\text { each worker }\end{array}$ & 3.0 & 3.0 & 3.2 & 2.0 & 2.0 & 2.9 \\
\hline $\begin{array}{l}\text { The execution of task has a } \\
\text { pre-defined time and method }\end{array}$ & 3.5 & 3.3 & 3.3 & 3.0 & 3.0 & 3.3 \\
\hline $\begin{array}{l}\text { Foremen/team chiefs have as } \\
\text { main function the supervision } \\
\text { and execution of directives }\end{array}$ & 4.0 & 3.3 & 3.7 & 3.5 & 4.0 & 3.7 \\
\hline $\begin{array}{l}\text { Only top managers and intermediate } \\
\text { chiefs/technicians are responsible } \\
\text { for the conception and/or control } \\
\text { of work process (workers do not take } \\
\text { decisions on labour related issues) }\end{array}$ & 3.0 & 3.7 & 3.5 & 3.5 & 3.0 & 3.4 \\
\hline $\begin{array}{l}\text { Work is performed individually } \\
\text { and not in group }\end{array}$ & 3.0 & 3.0 & 2.7 & 2.5 & 3.0 & 2.8 \\
\hline
\end{tabular}

Source: Author's calculations based on data gathered from direct interviews and questionnaires to fourteen Portuguese textiles firms between November 1998 and January 1999.

led to any change in the firms' existing labour organization processes, which is symptomatic of the absence of organizational dynamism on the part of the majority of the firms in the analysis.

In fact, eight of the 14 firms in the analysis (one belonging to the "strong growth" cluster) stated that with the acquisition and internal deployment of new technologies no qualitative change occurred at the level of the workforce and in the structure of organization of the firms' activities. Only three firms (two belonging to the first two performance clusters) reported significant changes in work organization. In terms of perspectives relative to qualitative (and quantitative) changes in employment structure, the scene is also characterized by clear inertia. On average, only four firms (from 12 valid responses) foresee a change in employment structure. 
TABLE 5

Organisational competences - impact of the acquisition of new technologies at the employment level (chief executives' opinion)

\begin{tabular}{lcccc}
\hline & None & Some & Strong & No. Firms \\
Very strong & 1 & 1 & 1 & 2 \\
Strong & 5 & 1 & 1 & 3 \\
Moderate & 1 & 1 & 1 & 6 \\
Weak & 1 & & & 2 \\
Decline & 8 & 3 & 3 & 1 \\
No. firms & & & & 14 \\
\hline
\end{tabular}

Source: Author's calculations based on data gathered from direct interviews and questionnaires to fourteen Portuguese textiles firms between November 1998 and January 1999.

\subsection{Linkage competences}

The percentage of routine and innovation actions jointly performed by the firm and external entities demonstrates the weak level of linkage competences exhibited by the generality of selected firms. On average, of the eleven market actions usually performed by firms, just two (22\%) are carried out with external support. Market actions present the worst performance in terms of external interrelationships, with only $22 \%$ (13\%) of the routine (innovation) actions being accomplished with the cooperation of external entities. It is at the level of the process that larger cooperation opportunities exist. This is due, in large part, to the services rendered by equipment suppliers (in the deployment of equipment and training of staff) and to specialized services, namely, laboratory and experimental analyses, as well as certification processes, usually carried out with the help of technological centres (e.g., CITEVE - Technological Centre of Portuguese Textile and Clothing Industry).

Essentially, sub-contracting is restricted to very simple, labour-intensive tasks. These latter are sub-contracted to small local firms, which are limited to passively producing, without adding little value to products created by the subcontractor company. The subcontractor company intervenes mainly at the level of quality control; thus, the transfer of any technical, organizational or commercial knowhow is practically absent, and the same applies to joint vocational training actions. 
TABLE 6

Linkage competences - market, product and process actions jointly performed by the firm and external entities ${ }^{(1)}$ (as percentage of each action type's total)

\begin{tabular}{|c|c|c|c|c|c|c|}
\hline & \multicolumn{3}{|c|}{ Routine actions } & \multicolumn{3}{|c|}{ Innovation actions } \\
\hline & Market & Product & Process & Market & Product & Process \\
\hline Very strong & 27 & 33 & 50 & 25 & 25 & 33 \\
\hline Strong & 27 & 55 & 33 & 25 & 33 & 37 \\
\hline Moderate & 12 & 22 & 38 & 8 & 5 & 28 \\
\hline Weak & 27 & 8 & 50 & 0 & 25 & 56 \\
\hline Decline & 36 & 0 & 0 & 0 & 25 & 11 \\
\hline Overall Average & 22 & 27 & 38 & 13 & 18 & 33 \\
\hline
\end{tabular}

Notes: (1) customers, suppliers, consultants, employers/industry associations, technological centres, universities/institutes, others

Source: Author's calculations based on data gathered from direct interviews and questionnaires to fourteen Portuguese textiles firms between November 1998 and January 1999.

To the extent that complex sub-contracting requires the addition of skilled labour the absence of any capacity to do more of this type of sub-contracting may be a consequence of inertia in two respects. Firstly, there is no one to manage the process in the outsourcing company, and secondly the capacities of the contractor companies to undertake more complex functions is limited by their own inertia (absence of more skilled people to structure deals).

\section{Human capital and firm technological competences}

\subsection{The "fission" hypothesis revisited. Qualitative evidence}

There is a clear, common pattern to the process by which the firms included in this case-study emerged. In the majority of cases, interviewed entrepreneurs had formerly been top skilled employees in neighbouring firms. ${ }^{26}$ According to

\footnotetext{
${ }^{26}$ In eight out of 14 firms, the owner/entrepreneur was a previous top skilled worker of a similar activity, local firm. Of the remaining six, in one (whose beginning of activity dates from the nineteen century) it was not possible to find its genesis, and another emerged from a partnership of wool retailers aiming to guarantee the sale of their raw material, other two were created by people previously unrelated to the textile business, and the other two firms, previously owned and managed by a well-know family with major textile interests, now are managed by professional boards, whose members came from other rival firms.
} 
the testimonies of respondents, firm evolution processes, at least in terms of skill patterns, were very similar; firm skill patterns tended to "imitate" the human capital configuration of entrepreneurs' former firms, characterized by a limited core of top skilled and top educated workers and a large number of low paid, undifferentiated workers.

Thus, corroborating the fission hypothesis put forward in Teixeira (2002b; 2003), the process of the emergence of the firms in study implied, in general, the exit of some (or, in certain cases all) the top skilled or educated workers from the "old" firm. In general, the "old" firms lost vital knowledge and experience when these people left. Such departures occurred, as the factual evidence collected here shows, simultaneously with the spin-off of a new venture by those (then) former employees who set up firms, which often were in competition with their former employers. The pervasiveness of this reproduction pattern, and the concomitant high expected fission risk explain, in large extent, the observed inertia in the human capital side of this group of selected firms.

There is a common employment pattern in terms of human capital within the Portuguese textile industry that is also apparent in the firms selected for the present study - "limited core of top educated and skilled workers and a large 'reserve army' of low educated and skilled workers'. Aggregating firms into clusters does not tone down such evidence, actually quite the opposite happens.

From Table 7 the inertia characterizing human capital decisions of this group of firms is apparent. The absolute number of entries (for both "top educated" and "top skilled") is very small in the group of firms studied. During the whole of 1997, on average, two "top educated" had entry into those firms, and the corresponding figure for "top skilled" is one. The turnover at the level of top educated and top skilled employment is relatively high in the highest performance clusters, which contrasts with the "moderate" cluster for which the turnover is nil. Taking into account the size of these two clusters in terms of total number of workers, the marginal risk of (radical) fission becomes much reduced for the "very strong" performance cluster compared to that for the "moderate" cluster. This explains the inert behaviour of this latter. The discrepancy in performance presented by "very strong" and "strong" clusters compared to the cluster in "decline", despite similar weights of top educated and top skilled exit employment flows in the corresponding total, can be rationalized within the "fission" argument. 
TABLE 7

The importance of 'top educated' and 'top skilled' workers in firm total employment and entry and exit flows (mean value within clusters)

\begin{tabular}{|c|c|c|c|c|c|c|c|c|c|c|}
\hline & \multirow{3}{*}{ \% Total Empl. } & \multicolumn{4}{|c|}{ Top educated } & \multicolumn{5}{|c|}{ Top skilled } \\
\hline & & \multicolumn{2}{|c|}{ Entries } & \multicolumn{2}{|c|}{ Exits } & \multirow[t]{2}{*}{ \% Total Empl. } & \multicolumn{2}{|c|}{ Entries } & \multicolumn{2}{|c|}{ Exits } \\
\hline & & no. & $\%$ Total & no. & $\%$ Total & & no. & $\%$ Total & no. & $\%$ Total \\
\hline Very strong & 2.7 & 5 & 4.4 & 5 & 10.6 & 4.9 & 3 & 2.2 & 4 & 6.9 \\
\hline Strong & 2.9 & $2^{1}$ & $6.3^{1}$ & $0^{1}$ & $6.3^{1}$ & 3.7 & $2^{1}$ & $6.3^{1}$ & 5 & 7.6 \\
\hline Moderate & 2.7 & $\mathrm{O}^{2}$ & $0.0^{2}$ & $0^{2}$ & $0.0^{2}$ & 6.5 & $0^{2}$ & $1.3^{2}$ & 0 & 1.6 \\
\hline Weak & 3.5 & 1 & 2.1 & 0 & 0.0 & 5.5 & 1 & 2.1 & 0 & 0.0 \\
\hline Decline & 2.4 & 1 & 4.8 & 1 & 7.7 & 3.3 & 1 & 1.0 & 2 & 15.4 \\
\hline Average & 2.8 & 2 & 3.5 & 1 & 4.9 & 4.7 & 1 & 2.6 & 2 & 6.3 \\
\hline
\end{tabular}

Notes: Recall that the data refer to 1997; ${ }^{1}$ the data refers to only 1 of the 3 firms that constitute the cluster; ${ }^{2}$ average of 5 out of 6 firms that constitute the cluster; The nil values in several clusters do not result from the "averaging-out" of firm value. In these cases the variance within each cluster concerning employment flows is zero or very close to it.

Source: Author's calculations based on data gathered from direct interviews and questionnaires to fourteen Portuguese textiles firms between November 1998 and January 1999.

In fact, as information gathered from the interviews elucidated, the number of top educated and skilled individuals in firms in the highest performance clusters is slightly above the "optimum" level. This "spare capacity" in human capital was justified by the chief executives as the desire to avoid slumps in their performance which might be provoked by unexpected exits of top educated and skilled individuals. The firm in the "decline" cluster, in contrast, had lost valuable top educated and skilled individuals in recent years and had not compensated for these exits with a corresponding number of entries. ${ }^{27}$

\subsection{The accumulation of human capital and firm training policy}

Firms, especially those belonging to the most dynamic clusters, tend to consider worker training unavoidable for good performance. Moreover, training

\footnotetext{
27 This situation further aggravated this firm's weak performance, which, according to its chief executive, derived in the first place from sluggish evolution of demand for its products. In spite of the fact that the data available did not allow quantitative assessment of the extent of the incapacity of the firm to deal with the slow down in its market, derived from the exit of top educated and skilled workers, the in-depth analysis of the firm uncovered at least some simultaneous causality between the "fission" process and performance.
} 
is seen, in general, as a cost with considerable positive externalities in the local productive system.

It is important to highlight that top skilled workers benefit from firm's training activities to a much greater extent than do the other workers. Data available from the firms selected indicates that "training share" (i.e., the importance of these types of workers in firm's training actions, measured in terms of hours and as an average for the period 1993-1997) of top skilled workers is approximately $48 \%$. All the remaining categories (foremen, highly skilled and skilled, low and non-skilled, and apprentices) present a "training share" below $15 \%$.

In general, the main reasons pointed to by firms to carry out or participate in training activities are associated with the need to adapt workers to the introduction of new equipment, changes in work organization and, to a lesser extent, the introduction of new mixes of products.

In the last five years under consideration (1992-1997), for firms that experienced the highest productivity rates, training was conducted mainly to adapt and prepare workers quickly for changes in the level of equipment, organization and, especially, changes in product mixes. It is this last aspect that distinguishes the first two clusters from the rest for whom product innovation does not seem to justify the deployment of training actions. Such evidence is also corroborated by the analysis of competences at product level, which shows that "moderate growth" and "weak growth" clusters presented the worst innovation rates.

Training seems here (and to an even greater extent for the "very strong growth" cluster) to have an essentially passive character, and be subject to shortterm reasoning. Thus, firms undertake training actions mainly in order to quickly adapt and prepare workers for technological changes (technical, organizational and product-related changes), relegating to secondary importance more active, long-term justifications, such as increasing workers' capacity to face future technological changes or increasing the innovation capacities and creativity of those same workers. Firms that constitute "strong growth" and "weak growth" clusters, however, show some positive signs in this domain by attributing some relevance to the long-term effects of training.

These particular features of training decisions among the firms in the study 
TABLE 8

Reasons for undertaking (or participating in) training actions

\begin{tabular}{|c|c|c|c|c|c|}
\hline & Very strong & Strong & Moderate & Weak & $\begin{array}{l}\text { Overall } \\
\text { average }\end{array}$ \\
\hline \multicolumn{6}{|l|}{ Adapting } \\
\hline Technical changes/new equipment & 4.5 & 4.7 & 4.5 & 4.0 & 4.5 \\
\hline New organisational models & 4.5 & 4.7 & 3.7 & 5.0 & 4.2 \\
\hline \multirow[t]{2}{*}{ New product mix } & 4.5 & 4.3 & 2.3 & 2.0 & 3.1 \\
\hline & 4.5 & 4.6 & 3.5 & 3.7 & 3.9 \\
\hline \multicolumn{6}{|l|}{ Quick prepare workers for } \\
\hline New equipment & 4.5 & 4.3 & 3.3 & 4.0 & 3.8 \\
\hline New organisational models & 4.5 & 4.3 & 2.2 & 5.0 & 3.5 \\
\hline \multirow[t]{2}{*}{ New product mix } & 4.5 & 4.7 & 2.0 & 2.5 & 3.1 \\
\hline & 4.5 & 4.4 & 2.5 & 3.8 & 3.5 \\
\hline \multicolumn{6}{|l|}{ Changes in tasks contents due to new } \\
\hline information technologies (NIT) & 4.0 & 3.3 & 4.0 & 4.0 & 3.8 \\
\hline \multicolumn{6}{|l|}{ Increase workers' capabilities for } \\
\hline Future technological changes & 2.5 & 4.3 & 2.8 & 4.5 & 3.4 \\
\hline \multirow[t]{2}{*}{ Innovate } & 1.0 & 3.7 & 2.7 & 2.5 & 2.6 \\
\hline & 1.8 & 4.0 & 2.8 & 3.5 & 3.0 \\
\hline Motivate workers & 1.5 & 3.7 & 2.8 & 3.5 & 2.9 \\
\hline Select the most capable workers & 2.5 & 2.3 & 2.7 & 3.0 & 2.6 \\
\hline Satisfying public supporting programmes & 1.0 & 2.3 & 3.0 & 2.5 & 2.5 \\
\hline \multicolumn{6}{|l|}{$\begin{array}{l}\text { Overcome recruitment difficulties } \\
\text { of given skills due to }\end{array}$} \\
\hline Their high cost & 1.0 & 2.0 & 2.2 & 3.5 & 2.2 \\
\hline Their real shortage & 2.0 & 4.3 & 2.2 & 3.5 & 2.8 \\
\hline
\end{tabular}

Note: 1 - Irrelevant... 5 - Very important

Source: Author's calculations based on data gathered from direct interviews and questionnaires to fourteen Portuguese textiles firms between November 1998 and January 1999.

cannot be dissociated from the "fission" argument. As shown in Teixeira (2002b), a high number of exits among top skilled and educated workers are likely to lead to a decline in the performance of firms. In this context, the decision of the selected firms to opt for short-term instead of more active-led and worker enhancing training actions, is perfectly rational. In opting for such types of training actions, firms avoid enhancing the "transferable" human capital stock of their workers, and thus minimises the potential for decline in the firm performance. Regarding the firms included in the "strong growth" and "weak growth" clusters, their more "pro-active" behaviour towards training derives, in part, from their lower marginal risk of radical fission given their larger absolute 
numbers of such workers. Moreover, their relative strong financial position is likely to enhance their capacity to retain (at least a "satisfactory" number of) top skilled and educated workers.

\subsection{Human capital and the acquisition of new technologies}

For the majority of the selected firms the acquisition of new technologies (essentially, new equipment) did not call for different skills or higher human capital levels in the workforce.

In the most dynamic clusters ("very strong growth" and "strong growth"), two firms confirmed that they had had to hire new workers, one during and after and the other before, during and after the acquisition of new technologies. In this latter case (which refers to a firm in the "very strong growth" cluster), the need to recruit top skilled personnel did not derive from the introduction of new equipment, but rather from changes in product strategy.

At least for the majority (67\%) of selected firms, undertaking training actions seemed to be demanded by the introduction of new technologies. For the majority of firms, however, training actions were occasional and encompassing a very reduced number of workers not having therefore impact on the average level of skills and educations of their workforce. In fact, systematic training activities only take place in higher performance firms. In such firms, training actions are carried out before, during and after the introduction of new technologies. The firm included in the "decline" cluster despite pro-active behaviour in terms of training activities, did not display any continuity in such activities; thus, at least in part, this fact is likely to explain the weak performance of this company in terms of productivity.

\subsection{Human capital and innovation capabilities}

\subsubsection{Market innovation}

The results of the inquiry show that firms in the study consider their existing human capital endowments, in particular their current top educated and top skilled workers, an important factor of their market innovation capabilities (3.8 on a scale of 5.0). Recent recruitment of top educated and skilled individuals, 
however, was not seen as an important contributor to those same capabilities (2.0 in a scale of 5.0). This fact however seems trivial as recent hirings tend to have less experience and thus are likely to contribute less than their experienced counterparts. But in considering another perspective of this evidence, the fact that, as reported above, market strategies are essentially entrepreneurially driven leads to the absence of any economic incentive for hiring highly human capital endowed individuals, and thus justifies the inertia observed in this context. Moreover, this is "congruent" with the pervasiveness of the fission risk and further enhances inertia in human capital demand. According to chief executives, the main factors contributing to firm market innovation performance are, alongside their existing endowments of human capital, customers' tastes and contacts with clients.

TABLE 9

Human capital and technological competences - market innovation capabilities

\begin{tabular}{|c|c|c|c|c|c|c|c|c|}
\hline & \multicolumn{8}{|c|}{$\begin{array}{l}\text { Factors which enhance market innovation } \\
\qquad(1 \text { - Irrelevant .. } 5 \text { - Critical })\end{array}$} \\
\hline & \multicolumn{2}{|c|}{ Human Capital } & \multirow[b]{2}{*}{$\begin{array}{c}\text { Fair } \\
\text { attendance }\end{array}$} & \multirow[b]{2}{*}{$\begin{array}{l}\text { Customer } \\
\text { preferences }\end{array}$} & \multirow[b]{2}{*}{$\begin{array}{l}\text { Competition } \\
\text { pressure }\end{array}$} & \multicolumn{3}{|c|}{ Contacts } \\
\hline & $\begin{array}{c}\text { Existing } \\
\text { Top }\end{array}$ & $\begin{array}{l}\text { New } \\
\text { Hiring }\end{array}$ & & & & $\begin{array}{l}\text { Customers/ } \\
\text { suppliers }\end{array}$ & Other firms & Universities \\
\hline Very strong & 3.0 & 1.8 & 3.5 & 4.0 & 3.0 & 3.5 & 1.5 & 2.0 \\
\hline Strong & 4.3 & 2.1 & 4.3 & 4.3 & 3.7 & 3.7 & 2.0 & 2.3 \\
\hline Moderate & 2.8 & 1.6 & 3.2 & 3.8 & 2.2 & 3.6 & 1.8 & 1.8 \\
\hline Weak & 4.0 & 3.0 & 4.5 & 2.0 & 3.0 & 4.0 & 2.0 & 3.0 \\
\hline Decline & 5.0 & 2.0 & 3.0 & 3.0 & 4.0 & 4.0 & 3.0 & 3.0 \\
\hline Global Average & 3.8 & 2.0 & 3.7 & 3.4 & 3.2 & 3.8 & 2.1 & 2.4 \\
\hline
\end{tabular}

Note: "Existing Top" means a firm's current top educated and top skilled workers; "New hiring" respects recently or prospective hiring of top skilled and top educated workers.

Source: Author's calculations based on data gathered from direct interviews and questionnaires to fourteen Portuguese textiles firms between November 1998 and January 1999.

\subsubsection{Product and process innovation}

Among the factors that might enhance product and/or process innovation the generality of clusters gives primacy to the "existing" top skilled and educated workforce. In the case of the "strong growth" cluster, the most relevant position 
is assigned to existing top educated and top skilled workers (4.7 out of 5.0) followed by the internal efforts in research and development (R\&D) (4.3), contacts with clients and suppliers (4.3), and environmental restrictions (4.3).

TABLE 10

Human capital and technological competences - product and process innovation capabilities

\begin{tabular}{|c|c|c|c|c|c|c|c|c|c|c|c|c|}
\hline & & & & Facto & rs which & $\begin{array}{l}\text { enhance } \\
1 \text { - Irrelev }\end{array}$ & $\begin{array}{l}\text { product } \\
\text { vant ... } 5\end{array}$ & $\begin{array}{l}\text { and pro } \\
\text { - Critico }\end{array}$ & $\begin{array}{l}\text { ocess inn } \\
\text { al) }\end{array}$ & pvation & & \\
\hline & Human & Capital & & & & & & & & Con & tacts & \\
\hline & $\begin{array}{l}\text { Existing } \\
\text { Top }\end{array}$ & $\begin{array}{l}\text { New } \\
\text { Hiring }\end{array}$ & & Know. & $\begin{array}{c}\text { on manage- } \\
\text { ment }\end{array}$ & $\begin{array}{l}\text { factor } \\
\text { prices }\end{array}$ & $\begin{array}{c}\text { ment } \\
\text { constraints }\end{array}$ & $\begin{array}{l}\text { Incentive } \\
\text { System }\end{array}$ & attendance & $\begin{array}{l}\text { Customers/ } \\
\text { suppliers }\end{array}$ & $\begin{array}{l}\text { Other } \\
\text { firms }\end{array}$ & $\begin{array}{c}\text { Univer- } \\
\text { sities }\end{array}$ \\
\hline Very strong & 4.0 & 2.3 & 2.5 & 2.5 & 2.0 & 2.5 & 2.0 & 2.5 & 3.0 & 3.5 & 1.5 & 2.0 \\
\hline Strong & 4.7 & 2.7 & 4.3 & 4.0 & 4.0 & 3.0 & 4.3 & 3.0 & 4.0 & 3.7 & 2.0 & 2.3 \\
\hline Moderate & 3.3 & 2.3 & 3.5 & 3.5 & 4.0 & 1.8 & 2.8 & 3.2 & 3.2 & 3.6 & 1.8 & 1.8 \\
\hline Weak & 4.0 & 2.8 & 4.5 & 3.5 & 4.0 & 3.5 & 4.0 & 4.5 & 4.0 & 4.0 & 2.0 & 3.0 \\
\hline Decline & 5.0 & 3.0 & 3.0 & 3.5 & 1.0 & 4.0 & 1.0 & 4.0 & 2.0 & 4.0 & 3.0 & 3.0 \\
\hline Average & 4.2 & 2.5 & 3.6 & 3.4 & 3.0 & 2.4 & 2.8 & 3.3 & 3.2 & 3.8 & 2.1 & 2.4 \\
\hline
\end{tabular}

Note: "Existing Top" means a firm's current top educated and top skilled workers; "New hiring" respects recently or prospective hiring of top skilled and top educated workers.

Source: Author's calculations based on data gathered from direct interviews and questionnaires to fourteen Portuguese textiles firms between November 1998 and January 1999.

As observed in the above discussion of market-related innovation factors, the evidence gathered here seems to be congruent with the "fission" argument and the inertia on the human capital side.

\section{Conclusion}

Firms selected for the case-study analysis, similarly to the vast majority of Portuguese textile firms, and regardless of their performance dynamics, seem to present a conscious and intentional behaviour towards rather technologically stable production processes, characterized by a relative high intensity of labour and not requiring significant amounts of highly endowed human capital resources. Strategies at market or distribution levels are essentially entrepreneurially driven and subcontracting practices tend to be confined to

I96 Revista Brasileira de Inovação 
relatively simple tasks that do not require substantial input of human capital. Labour organization features also highlight the labour intensive character of firms' processes and their relative inertia. This latter aspect is particularly striking in the behaviour of firms regarding the deployment of new technology. In a context pervaded by fission risk, such behaviour and characteristics in their production process are likely to magnify even further the inertia observed on the human capital side.

The discussion of the contributing factors for firm market, product and process-related innovation uncovers the "congruence" between their (inert) behaviour towards human capital accumulation, the characteristics of their productive process and markets (stability of labour intensive character and little diversification of products), and the omnipresent "fission" risk. New hirings of top skilled and educated individuals are seen as small contributors to the (current) innovation capabilities of firms in terms of market, product or processes. In contrast, existing top skilled and educated individuals are regarded as critical in this context. In this vein, inert behaviour towards human capital accumulation seems to be, in fact, the most economically rational strategy, confirming the results of the database estimation exercise undertaken by Teixeira (2003).

Although the present work focused only the innovative aspects related to the productive performance and, more specifically, the human capital demand, the methodology employed allows the inclusion of a broader list of firm attributes. In fact, the multivariate method permits the inclusion of new variables - such as size indicators (sales, number of employees), external orientation (percentage of production exported, percentage of inputs imported), externalities (institutional participation, linkages), tertiarization (productive phases subcontracted), etc. which could better characterize firms analysed, enabling to define more comprehensively firm profiles without compromising statistical robustness. Moreover, cluster analysis could be complemented with Principal Component Analysis, which would position variables, and its attributes in the same analytical plan easing results interpretations.

Despite the restricted scope of the empirical application, focusing on one country (Portugal) and one industry (textiles), the theoretical framework nevertheless could be applied to other countries/regions and industries facing similar social, institutional and industrial features as the example used here. In 
particular, those cases combining three main characteristics: 1) a labour market where (geographical and occupational) mobility is limited; 2) industries where top educated and skilled individuals are highly valued but for which only a small number of these types of workers is needed to (successfully) run the business; and 3) countries/regions where there is a history and tradition of new firm formation.

NOTA: os questionários aplicados, e que serviram de base aos resultados apresentados no artigo, encontram-se à disposição mediante solicitação no endereço rbi@finep.gov.br

I98 Revista Brasileira de Inovação 


\section{References}

Afonso, O.; Aguiar, A., "O Contributo do Comércio Externo para o Crescimento Económico Português, 1960-1993", Paper presented at “6Encontro Economia Industrial”, Lisboa, 3-4, out., 1997, Centro de Estudos Aplicados da Universidade Católica Portuguesa, 1997.

APIM, 2ํㅜㅇórum da Indústria Têxtil. "A Têxtil Desafia os Políticos. Balanço e Conclusōes", Brochura APIM, 1998.

Ashton, D.; Green, F., Education, Training and the Global Economy, Cheltenham, UK, Brookfield, US: Edward Elgar, 1996.

Batista, M., Educação - Mercado de Trabalho, DEP GEF, Portugal: Ministério da Educação, Departamento de Programação e Gestão Financeira, 1994.

Os Diplomados do Ensino Superior: a Problemática da Inserção na Vida Activa, Lisboa: Departamento de programação e Gestão Financeira do ME, 1996.

Becker, G., "Investments in Human Capital: a Theoretical Analysis", in Journal of Political Economy, v.70, p.9-44, 1962.

GEPIE, A Induistria Portuguesa Horizonte 2015. Evolução e Prospectiva, GEPIE, Ministério da Indústria e Energia, 1995.

Godinho, M., Innovation Diffusion in the Portuguese and Italian Clothing Industry, D. Phil Thesis, SPRU, Sussex University, 1993.

Kovács, I., Moniz, A.; Cerdeira, M.; Albalate, J., Tendências da Indústria Electrónica na Peninsula Ibérica: Tecnologia, Gestão e Qualificação, Programa Force, CINEL, CESO I\&D, 1993.

Lopes, P., "Indústria Têxtil e do Vestuário no Contexto da Rregião Norte - Uma Análise Económica”, in IV Encontro Nacional APDR, Covilhã, 21 a 23 de novembro, 1996.

Lourenço, L.; Mendes, L., "A Indústria da Beira Interior e o Fenómeno da Qualidade", in $I V$ Encontro Nacional APDR, Covilhã, 21 a 23 de novembro, 1996.

Marx, K., O Capital, V. I, translated by Joaquim Pinto de Andrade and Ana Maria Barradas edited by Frederick Engels, published in 1974, Lisboa: PUF, 1887.

Navaretti, R.; Perosino, G., "Redeployment of Production, Trade Protection and Firms' Global Strategies: the Case of Italy", in G. Navaretti et al., Beyond the Multifibre arrangement. Third world competition and restructuring Europe's textile industry, p.169-191, 1995.

Norusis, M., SPSS Advanced Statistics 6.1, Chicago Ill.: SPSS Inc., 1994.

Piatti, L.; Spinanger, D., "Redeployment of Production, Trade Protection, and Firm Global Strategies: the Case of Germany", in G. Navaretti et al., Beyond the Multifibre Arrangement. Third World Competition and Restructuring Europe's Textile Industry, p.193-218, 1995. 
Schultz, T., "Investment in Human Capital", in American Economic Review, 51(1), p.1-17, 1961. , "The Concept of Human Capital: Reply”, in M. Blaug, Economics of Education, p.58-64, 1961 .

Senker, P.; Brady, T., "Corporate Strategy: Skills, Education and Training”, in M. Dodgson, Technology Strategy and the Firm: Management and Public Policy, Longman: a SPRU Publication, Ch. 10, p.155-169, 1989.

Singleton, J., The World Textile Industry, Routledge Competitive Advantage in World Industry, London: Routledge, 1997.

Stevens, M., Some Issues in the Economics of Training, DPhil Thesis, Nuffield College, Oxford, 1993.

Teixeira, A., Capital Humano e Capacidade de Inovação. Contributos para o Estudo do Crescimento Económico Português, 1960-1991, in Série Estudos e Documentos, Lisboa: Conselho Económico e Social, 1999.

, "On the Link Between Human Capital and Firm Performance. A Theoretical and Empirical Survey”, FEP Working Papers n 121, Novembro, 2002a.

, Fission Risk or Inertia? Human Capital Decisions in the Portuguese Textile Industry During the Eighties and Nineties, DPhil Thesis, SPRU, University of Sussex, 2002b.

, "Fission Risk or Inertia? Towards an Evolutionary-Ecological Model of Human Capital Decisions”, DRUID Winter Conference 2003, Aalborg (Danmark), 16-18, jan., 2003.

Yin, R. K., Case Study Research: Design and Methods, Londres: Sage, 1994. 